\title{
Assessment of the livelihood status of the fish farmers in some selected areas of Bagmara upazilla under Rajshahi district
}

\author{
M.H. Ali, M.D. Hossain ${ }^{1}$, A.N.G.M. Hasan ${ }^{2}$ and M.A. Bashar \\ Dept. of Aquaculture, Bangladesh Agricultural University, Mymensingh-2202, Bangladesh \\ ${ }^{1}$ Department of Fisheries, RU and ${ }^{2}$ Department of Fisheries Biology \& Genetics, Bangladesh \\ Agricultural University, Mymensingh-2202
}

\begin{abstract}
The present investigation was carried out to assess the livelihood status of the fish farmers in Hamirkutsha and Kamarbari Unions of Bagmara upazilla under Rajshahi district during June to December 2006. Data were collected through the use of well structured questionnaire. Fifty farmers were included in this study who were directly involved in fish farming. Average pond size was 0.13 ha with single (64\%) and multiple ownerships (36\%). Most of the fishers were belonged to the age category of 31 to 40 years and average education level of 9.86 years of schooling, represented by $94 \%$ Muslims and $6 \%$ Hindus. About $54 \%$ of the farmers have tinshed house while 26,14 and $6 \%$ of the farmers have half-building, building and kacha house, respectively. Average annual incomes of majority of fish farmers were above Tk. 75,000 per annum and $62 \%$ of the farmers used semi-pucca sanitary, $28 \%$ used pucca sanitary while only $10 \%$ used katcha sanitary. About $62 \%$ of the farmers had electricity facilities while $38 \%$ did not have and $88 \%$ of the farmers used own tube-well, while $12 \%$ of the farmers used neighbor's tube-well. Forty six percent of the farmers received health service from village doctor or kobiraj, $18 \%$ have access to upazila health complex, $14 \%$ went to district hospital, $20 \%$ consulted with MBBS doctor and $2 \%$ of the farmers do not take any treatment due to lack of money. Lack of scientific knowledge, multiple ownerships and lack of capital for fish culture were the major constraints.
\end{abstract}

Keywords: Constraints, Fish farmers, Health service and Livelihood status

\section{Introduction}

Livelihood comprises the capabilities, the assets (natural, physical, human, financial and social capital), the activities and the accesses to these (mediated by institutions and social relations) that together determine the living gained by the individual household (Chambers and Conway, 1992). A livelihood is sustainable when it can cope with and recover from stresses and shocks and maintain or enhance its capabilities and assets both now and in future, while not undermining the natural resource base (Chambers and Conway, 1992). About 12 million people (10\% of total population) directly or indirectly depend on fisheries sector for their livelihood (DoF, 2005). There are over 1.2 million fishermen in the country but almost two-thirds of the rural households get involved in fishing during the monsoon (DoF, 2005). Fish and fisheries are indispensable part in the life and livelihoods of the people of Bangladesh and it is the part of our cultural heritage. For sustainable rural development and poverty elimination, different approaches have been adopted and the "Sustainable Livelihood Approach" has been gradually expanded with its own core and principles for poverty focused development activities (DFID, 1998). The approach basically based on the fundamental principle analysis of capital assets (i.e. human capital, physical capital, financial capital, social capital and natural capital ) in the context of the external environment. According to Carney (1999), a sustainable livelihood approach is a way of thinking about the objectives, scope and priorities for development, in order to enhance progress in poverty elimination (Scones, 1998). Considering the financial hardship and other complexities of the rural fish farmers, it is important to analyze their livelihood status. In view of the above consideration; the present study was undertaken to determine the livelihood status of the fish farmers and to identify the socio-economic problems / constrains associated with fish farming. 


\section{Materials and Methods}

\section{Selection of the study area and target group}

Two Unions in Bagmara upazilla under Rajshahi district were selected for the study, because; pond fish culture is heavily concentrated in this area, various NGOs and DoF have been working with fish farmers to increase fish production, well communication facilities, relatively homogenous physiographic condition and finally, suitable for researcher work in this area. Data were collected during June to December 2006 in Hamirkutsha and Kamarbari Union. Fifty farmers were randomly selected from two unions of Bagmara upazilla. Fish pond with different types of culture system, management practices and farmers age, number of family member; religion status, income level, health facilities, sanitary facilities, get of technical assistance, electricity facilities etc. were included in the sample.

For data collection, a set of interview schedule was designed. Data were collected from the fish farmers using questionnaire interviews, Participatory Rural Appraisal (PRA) tools such as Focus Group Discussion (FGD) and Cross-check interview with key informants. Data were processed and finally analyzed using tabular method.

\section{Results and Discussion}

\section{Livelihood assets}

\section{Human Capital: Age distribution}

Out of total 50 farmers, $52 \%$ belonged to the age group of 31 to 40 years whereas only $6 \%$ are found in the group of above 51 years (Table 1).

Table 1. Age distribution of the fish farmers in the study area

\begin{tabular}{|l|c|c|c|}
\hline Age group (years) & Hamirkutsha $(\mathrm{n}-25)$ & Kamarbari $(\mathrm{n}-25)$ & Total $(\mathrm{N}-50)$ \\
\hline 20 to 30 & $3(12 \%)$ & $4(16 \%)$ & $7(14 \%)$ \\
\hline 31 to 40 & $14(56 \%)$ & $12(48 \%)$ & $26(52 \%)$ \\
\hline 41 to 50 & $6(24 \%)$ & $8(32 \%)$ & $14(28 \%)$ \\
\hline 51 and above & $1(4 \%)$ & $2(8 \%)$ & $3(6 \%)$ \\
\hline
\end{tabular}

${ }^{* *}$ Figure in the parenthesis indicates percentage of total, * Average age: 38.52 years

Family size: The family size of the fish farmers were divided into three categories according to the number of the family members (Table 2 ). About $52 \%$ of the respondents had $4-5$ family members, $28 \%$ had small family with $2-3$ members, while $20 \%$ had more than 6 family members.

Table 2. Family size of the fish farmers in the study area

\begin{tabular}{|l|c|c|c|}
\hline Family size & Hamirkutsha $(\mathrm{n}-25)$ & Kamarbari $(\mathrm{n}-25)$ & Total $(\mathrm{N}-50)$ \\
\hline $2-3$ & $9(36 \%)$ & $5(20 \%)$ & $14(28 \%)$ \\
\hline $4-5$ & $12(48 \%)$ & $14(56 \%)$ & $26(52 \%)$ \\
\hline$\geq 6$ & $4(16 \%)$ & $6(24 \%)$ & $10(20 \%)$ \\
\hline
\end{tabular}

${ }^{* *}$ Figure in the parenthesis indicates percentage of total, ${ }^{*}$ Average family size: 4.4 members

Family status: About $28 \%$ farmers lived with joint families and $72 \%$ lived with nuclear families. The highest number of farmers with nuclear family structures was found in Hamirkutsha (76\%) union than Kamarbari (68\%).

Education: Fifty percent of the fish farmers had education up to S.S.C level, while $22 \%$ had H.S.C level of education. About $6 \%$ of the farmers were illiterate, $4 \%$ of the respondents possessed bachelors' degree. 
Religious status: It was found that maximum fish farmers were Muslim $(94 \%)$ while small proportions $(6 \%)$ were Hindus (Table 4). Highest percentage of Muslims fish farmers were found in Kamarbari (96\%) whereas the increased number of Hindus (8\%) fish farmers were found in Hamirkutsha (Table 5).

Table 3. Family status of the fish farmers in the study area

\begin{tabular}{|l|c|c|c|}
\hline Family type & Hamirkutsha $(\mathrm{n}-25)$ & Kamarbari $(\mathrm{n}-25)$ & Total $(\mathrm{N}-50)$ \\
\hline Joint family & $6(24 \%)$ & $8(32 \%)$ & $14(28 \%)$ \\
\hline Nuclear family & $19(76 \%)$ & $17(68 \%)$ & $36(72 \%)$ \\
\hline
\end{tabular}

**Figure in the parenthesis indicate percentage of total

Table 4. Educational status of the fish farmers in the study area

\begin{tabular}{|l|c|c|c|}
\hline Educational level & Hamirkutsha $(\mathrm{n}-25)$ & Kamarbari $(\mathrm{n}-25)$ & Total $(\mathrm{N}-50)$ \\
\hline No education (Illiterate) & $2(8 \%)$ & $1(4 \%)$ & $3(6 \%)$ \\
\hline Only signature & $1(4 \%)$ & $1(4 \%)$ & $2(4 \%)$ \\
\hline Up to Primary & $4(16 \%)$ & $3(12 \%)$ & $7(14 \%)$ \\
\hline S.S.C & $12(48 \%)$ & $13(52 \%)$ & $25(50 \%)$ \\
\hline H.S.C & $6(24 \%)$ & $5(20 \%)$ & $11(22 \%)$ \\
\hline Bachelor & $0(0 \%)$ & $2(4 \%)$ & $2(4 \%)$ \\
\hline
\end{tabular}

**Figure in the parenthesis indicate percentage of total

Table 5. Religious status of the fish farmers in the study area

\begin{tabular}{|l|c|c|c|}
\hline Religion & Hamirkutsha $(\mathrm{n}-25)$ & Kamarbari $(\mathrm{n}-25)$ & Total $(\mathrm{N}=50)$ \\
\hline Muslims & $23(92 \%)$ & $24(96 \%)$ & $47(94 \%)$ \\
\hline Hindus & $2(8 \%)$ & $1(4 \%)$ & $3(6 \%)$ \\
\hline
\end{tabular}

**Figure in the parenthesis indicate percentage of total

Human capital represents the farmer's age, education, family size and status, religious status etc. Ahmed (2001) reported that human capital is skills, knowledge, education, ability of labor and good health that together enable people to pursue their livelihood strategies. As well as being of intrinsic value, human capital is required in order to make use of any of the four other types of assets. From the present study it was found that, only $10 \%$ got health service from MBBS doctors, while $46 \%$ of fish farmers were dependent on village doctors. The poor health and inadequate nutrition of the children, women and old-aged members of farming communities also inhibits their development. The poor health facilities, sanitary facilities and inadequate access to safe drinking water make their human assets and consequently the livelihoods more vulnerable. The similar views were also expressed by Ali (1991) and Biswas et al. (2000).

\section{Natural Capital: Pond size}

The average pond size in the study area was found to be 0.15 ha (37 decimals). The average pond size in Kamarbari was 0.16 ha which was larger than in Hamirkutsha (0.14 ha).

Type of pond: In the study area, $46 \%$ of the pond were seasonal and $54 \%$ pond were perennial (Table 7 ). The water level in the perennial ponds declined significantly during dry season and become unsuitable for fish culture. Some of the farmers filled their ponds up to 3$4 \mathrm{ft}$ level by pumping water from the nearly deep tube-well. Seasonal ponds become totally unsuitable for fish culture during dry season. 
Natural capital of farmers represents the natural resources such as land, water, timber and wider environmental goods that are critical for farmers and associated groups, to support the production. People often sell their timber to make up the income shortfalls, resulting to a loss of biodiversity. Rapid population growth has to some extent led to accelerate natural capital depletion that has affected their income. Presence of canal; beels and existence of floodplains in the vicinity of the study area offer tremendous scope for harnessing natural resources for sustainable livelihood management of the fish farmers and fishing community.

Table 6. Size of ponds (ha) in the surveyed area

\begin{tabular}{|l|c|c|c|}
\hline Parameter & Hamirkutsha & Kamarbari & Total (average) \\
\hline Range (ha) & $0.04-0.25$ & $0.03-0.29$ & \multirow{2}{*}{0.15} \\
\hline Average pond size (ha) & 0.14 & 0.16 & \\
\hline
\end{tabular}

Table 7. Distribution of the type of pond in the study area

\begin{tabular}{|l|c|c|c|}
\hline Pond type & Hamirkutsha $(\mathrm{n}-25)$ & Kamarbari $(\mathrm{n}-25)$ & Total $(\mathrm{N}-50)$ \\
\hline Seasonal & $11(44 \%)$ & $12(48 \%)$ & $23(46 \%)$ \\
\hline Perennial & $14(56 \%)$ & $13(53 \%)$ & $27(54 \%)$ \\
\hline
\end{tabular}

${ }^{* *}$ Figure in the parenthesis indicate percentage of total

\section{Physical Capital: Housing conditions}

The majority (54\%) of the respondents had tinshed, $26 \%$ had half building, $14 \%$ had building and only $6 \%$ had kacha house (Table 8 ).

Table 8. Housing condition of the fish farmers in the study area

\begin{tabular}{|l|c|c|c|}
\hline Housing condition & Hamirkutsha $(\mathrm{n}-25)$ & Kamarbari $(\mathrm{n}-25)$ & Total $(\mathrm{N}-50)$ \\
\hline Kacha & $2(8 \%)$ & $1(4 \%)$ & $3(6 \%)$ \\
\hline Tinshed & $13(52 \%)$ & $14(56 \%)$ & $27(54 \%)$ \\
\hline Half building & $7(28 \%)$ & $6(24 \%)$ & $13(26 \%)$ \\
\hline Building & $3(12 \%)$ & $4(16 \%)$ & $7(14 \%)$ \\
\hline
\end{tabular}

${ }^{* *}$ Figure in the parenthesis indicate percentage of total

Health facilities: When the farmers face health problem then initially most of them go to the village doctor / kobiraj (46\%). If the problem is severe then they go to upazila health complex (18\%), district hospital (14\%), and MBBS doctor (20\%). But a few farmers do not get any treatment $(2 \%)$ due to lack of money (Table 9$)$.

Table 9. Health service received by the fish farmers in the surveyed area

\begin{tabular}{|l|c|c|c|}
\hline Health service & Hamirkutsha $(\mathrm{n}-25)$ & Kamarbari $(\mathrm{n}-25)$ & Total $(\mathrm{N}-50)$ \\
\hline Village doctor / kobiraj & $11(44 \%)$ & $12(48 \%)$ & $23(46 \%)$ \\
\hline Upazila health complex & $6(24 \%)$ & $3(12 \%)$ & $9(18 \%)$ \\
\hline District hospital & $3(12 \%)$ & $4(16 \%)$ & $7(14 \%)$ \\
\hline MBBS doctor (private) & $4(16 \%)$ & $6(24 \%)$ & $10(20 \%)$ \\
\hline Do not get any treatment & $1(4 \%)$ & $\mathrm{O}(0 \%)$ & $1(2 \%)$ \\
\hline
\end{tabular}

${ }^{* *}$ Figure in the parenthesis indicate percentage of total

Drinking water facilities: In the study area, $88 \%$ of the fish farmers were used own tubewell and $12 \%$ of the farmers was used neighbor's tube-well for collecting drinking water (Table 10).

Electricity facilities: In the study area, it was found that $62 \%$ of the surveyed fish farmers have electricity facilities, whereas, $38 \%$ had no electricity facilities at their residence (Table 11). The farmers in Hamirkutsha union had more access to electricity $(64 \%)$ as compared to those in Kamarbari (44\%). 
Table 10. Drinking water facilities of the fish farmers in the study area

\begin{tabular}{|l|c|c|c|}
\hline Source of drinking water & Hamirkutsha $(n-25)$ & Kamarbari $(n-25)$ & Total $(\mathrm{N}-50)$ \\
\hline Own tube-well & $23(92 \%)$ & $21(84 \%)$ & $44(88 \%)$ \\
\hline Neighbor's tube-well & $2(8 \%)$ & $4(16 \%)$ & $6(12 \%)$ \\
\hline
\end{tabular}

${ }^{* *}$ Figure in the parenthesis indicate percentage of total

Table 11. Status of electricity facilities of the fish farmers in the study area

\begin{tabular}{|l|c|c|c|}
\hline Electricity facilities & Hamirkutsha $(\mathrm{n}-25)$ & Kamarbari $(\mathrm{n}-25)$ & Total $(\mathrm{N}-50)$ \\
\hline Yes & $16(64 \%)$ & $11(44 \%)$ & $31(62 \%)$ \\
\hline No & $9(36 \%)$ & $14(56 \%)$ & $19(38 \%)$ \\
\hline
\end{tabular}

${ }^{* *}$ Figure in the parenthesis indicate percentage of total

Sanitary facilities: It was observed that the farmers' sanitary conditions were very poor in the surveyed area and only $28 \%$ stated that they had these (Table 12). The farmers had higher access to good sanitation in Kamarbari (36\%) than Hamirkutsha (20\%). A few farmers noted that the households of fish farmers often suffered from diarrhea and cholera due to lack of good sanitary facilities.

Table 12. Use of sanitary facilities by the fish farmers in the study area

\begin{tabular}{|l|c|c|c|}
\hline Sanitary facilities & Hamirkutsha $(\mathrm{n}-25)$ & Kamarbari $(\mathrm{n}-25)$ & Total $(\mathrm{N}-50)$ \\
\hline Katcha & $3(12 \%)$ & $2(8 \%)$ & $5(10 \%)$ \\
\hline Semi-pucca & $17(68 \%)$ & $14(56 \%)$ & $31(62 \%)$ \\
\hline Pucca & $5(20 \%)$ & $9(36 \%)$ & $14(28 \%)$ \\
\hline
\end{tabular}

**Figure in the parenthesis indicate percentage of total

Cooking fuels: At about $56 \%$ of respondents stated that they mainly used paddy straw, while $24 \%$ and $20 \%$ used wood and cow-dung, respectively (Table 13).

Table 13. Use of cooking fuels by the fish farmers in the study area

\begin{tabular}{|l|c|c|c|}
\hline Cooking fuel & Hamirkutsha $(\mathrm{n}-25)$ & Kamarbari $(\mathrm{n}-25)$ & Total $(\mathrm{N}-50)$ \\
\hline Cow-dung & $4(16 \%)$ & $6(24 \%)$ & $10(20 \%)$ \\
\hline Paddy straw & $13(52 \%)$ & $15(60 \%)$ & $28(56 \%)$ \\
\hline Wood & $8(32 \%)$ & $4(16 \%)$ & $12(24 \%)$ \\
\hline
\end{tabular}

${ }^{* *}$ Figure in the parenthesis indicate percentage of total

The physical capital of fish farming is transport, drinking water supply, sanitary facilities, shelter, roads, market, electricity etc (DFID, 2000). The study showed that $88 \%$ of the farmers' household used their own tube-well for drinking water, while $12 \%$ used neighbor's tube-well. About $62 \%$ of the respondents stated that they had electricity. Poor physical capitals in turn affect higher production costs and lower production.

\section{Social Capital}

It was found that $60 \%$ of the farmers got technical assistance or advice on aquaculture from friends and neighbors. About $22 \%$ of the farmers acquired technical assistance from others (self-study), while $8 \%$ and $10 \%$ of the farmers got technical assistance from DoF and NGO, respectively.

Almost all fish farming people are disadvantaged in social capital such as the networks, groups, trust, access to institutions etc. Result of the present study showed poor existence of social organizations of the farmers. The lack of social capital has affected livelihoods of poor people in fish farming communities. The present findings agree well with the findings of Zaman (2006) and Hossain et al. (1992); while the opposite picture was noted by Sarker (2007) in Trishal upazila under Mymensingh district. The apparent difference in the functioning of social capital seems to be related with the localities and proximity to district town. 


\section{Financial Capital}

Annual house hold income: The selected fish farmers were grouped into five categories based on the level of their annual income. The $1^{\text {st }}$ category included the fish farmers having annual income up to $24,000 \mathrm{Tk}$. The $2^{\text {nd }}, 3^{\text {rd }}, 4^{\text {th }}$ and $5^{\text {th }}$ categories had income levels of Tk. 25,000-50,000; Tk. 51,000-75,000; Tk. 76,000-1,00,000 and $>1,00,000$ respectively (Table 15). It is evident that majority of the respondent farmers belonged to $4^{\text {th }}$ category. The $4^{\text {th }}$ category had the highest proportion $(36 \%)$ of farmers while the lowest proportions of farmers $(2 \%)$ were in the $1^{\text {st }}$ category.

Table 14. Source of technical assistance on aquaculture in the study area

\begin{tabular}{|l|c|c|c|}
\hline $\begin{array}{l}\text { Source of technical assistance on } \\
\text { aquaculture }\end{array}$ & $\begin{array}{c}\text { Hamirkutsha } \\
(\mathrm{n}-25)\end{array}$ & $\begin{array}{c}\text { Kamarbari } \\
(\mathrm{n}-25)\end{array}$ & $\begin{array}{c}\text { Total } \\
(\mathrm{N}-50)\end{array}$ \\
\hline DoF & $3(12 \%)$ & $1(4 \%)$ & $4(8 \%)$ \\
\hline NGO & $2(8 \%)$ & $3(12 \%)$ & $5(10 \%)$ \\
\hline Friends and neighbors & $14(56 \%)$ & $16(64 \%)$ & $30(60 \%)$ \\
\hline Others & $6(24 \%)$ & $5(20 \%)$ & $11(22 \%)$ \\
\hline
\end{tabular}

${ }^{* *}$ Figure in the parenthesis indicate percentage of total

Table 15. Annual incomes of the fish farmers in the study area

\begin{tabular}{|l|c|c|c|}
\hline Annual house hold income (Tk.) & Hamirkutsha $(\mathrm{n}-25)$ & Kamarbari $(\mathrm{n}-25)$ & Total $(\mathrm{N}-50)$ \\
\hline Up to 24,000 & $1(4 \%)$ & $0(0 \%)$ & $1(2 \%)$ \\
\hline $24,001-50,000$ & $6(24 \%)$ & $4(16 \%)$ & $10(20 \%)$ \\
\hline $50,001-75,000$ & $5(20 \%)$ & $10(40 \%)$ & $15(30 \%)$ \\
\hline $75,001-1,00,000$ & $11(44 \%)$ & $7(28 \%)$ & $18(36 \%)$ \\
\hline$>1,00,000$ & $2(8 \%)$ & $4(16 \%)$ & $6(12 \%)$ \\
\hline
\end{tabular}

${ }^{* \star}$ Figure in the parenthesis indicate percentage of total

Occupation: Primary occupation: Almost all respondents $(60 \%)$ reported agriculture is their primary occupation. However, as a primary occupation, $14 \%$ of respondents stated that fish farming is their primary occupation, while $18 \%$ and $8 \%$ are occupied in business and service, respectively (Table 16).

Table 16. Primary occupation by fish farmers in the surveyed area

\begin{tabular}{|l|c|c|c|}
\hline Occupation & Hamirkutsha $(\mathrm{n}-25)$ & Kamarbari $(\mathrm{n}-25)$ & Total $(\mathrm{N}-50)$ \\
\hline Agriculture & $14(56 \%)$ & $16(64 \%)$ & $30(60 \%)$ \\
\hline Fish culture & $3(12 \%)$ & $4(16 \%)$ & $7(14 \%)$ \\
\hline Business & $5(20 \%)$ & $4(16 \%)$ & $9(18 \%)$ \\
\hline Service & $3(12 \%)$ & $1(4 \%)$ & $4(8 \%)$ \\
\hline
\end{tabular}

**Figure in the parenthesis indicate percentage of total

Secondary occupation: Forty eight percent of respondents stated that their secondary occupation is agriculture while $20 \%$ and $30 \%$ are occupied in fish farming and business respectively (Table 17).

Table 17. Secondary occupation by fish farmers in the surveyed area

\begin{tabular}{|l|c|c|c|}
\hline Occupation & Hamirkutsha $(\mathrm{n}-25)$ & Kamarbari $(\mathrm{n}-25)$ & Total $(\mathrm{N}-50)$ \\
\hline Agriculture & $11(44 \%)$ & $13(52 \%)$ & $24(48 \%)$ \\
\hline Fish culture & $6(24 \%)$ & $4(16 \%)$ & $10(20 \%)$ \\
\hline Business & $7(28 \%)$ & $8(32 \%)$ & $15(30 \%)$ \\
\hline Service & $1(4 \%)$ & $0(0 \%)$ & $1(2 \%)$ \\
\hline
\end{tabular}

${ }^{* *}$ Figure in the parenthesis indicate percentage of total 
Savings: It was found that $38 \%$ of respondents had savings (Table 18). The farmers could save some from agriculture, fish culture, business, service and other activities. However, the rest of $62 \%$ farmers could not save money due to poor resources and household expenses.

Table 18. Savings by farmers in the study area

\begin{tabular}{|l|c|c|c|}
\hline Savings & Hamirkutsha $(\mathrm{n}-25)$ & Kamarbari $(\mathrm{n}-25)$ & Total $(\mathrm{N}-50)$ \\
\hline Yes & $11(44 \%)$ & $8(32 \%)$ & $19(38 \%)$ \\
\hline No & $14(56 \%)$ & $17(68 \%)$ & $31(62 \%)$ \\
\hline
\end{tabular}

${ }^{* *}$ Figure in the parenthesis indicate percentage of total

Pond ownership: In the study area, $64 \%$ of the ponds were under single ownership and $36 \%$ under multiple ownership (Table 19).

Table 19. Ownership of the ponds in the study area

\begin{tabular}{|l|c|c|c|}
\hline Ownership & Hamirkutsha $(\mathrm{n}-25)$ & Kamarbari $(\mathrm{n}-25)$ & Total $(\mathrm{N}-50)$ \\
\hline Single & $17(68 \%)$ & $15(60 \%)$ & $32(64 \%)$ \\
\hline Multiple & $8(32 \%)$ & $10(40 \%)$ & $18(36 \%)$ \\
\hline
\end{tabular}

${ }^{* *}$ Figure in the parenthesis indicate percentage of total

Table 20. Loan received by farmers for farming in the study area

\begin{tabular}{|l|c|c|c|}
\hline Received Ioan & Hamirkutsha $(\mathrm{n}-25)$ & Kamarbari $(\mathrm{n}-25)$ & Total $(\mathrm{N}-50)$ \\
\hline Yes & $6(24 \%)$ & $4(16 \%)$ & $10(20 \%)$ \\
\hline No & $19(76 \%)$ & $21(84 \%)$ & $40(80 \%)$ \\
\hline
\end{tabular}

${ }^{* *}$ Figure in the parenthesis indicate percentage of total

Credit facilities: It was found that, $80 \%$ of farmers used their own money for fish farming, while the rest $(20 \%)$ of the farmers received loans. Twenty four percent of fish farmers of Hamirkutsha union received loans where $16 \%$ in case of Kamarbari. In recent years several institutions such as, banks, NGOs, moneylenders (mohazon) etc. are providing credit to the farmers.

Financial capital denotes the financial resources that people use to achieve their livelihood objectives. Financial capital of fish farmers represents income, occupation, savings, credit etc. The fish farming sector has the potential to generate considerable amounts of financial capital to the resources of associated groups. However, the study showed that small farmers suffer more from lack of adequate financial resources. The similar situations were also noted by Sarker (2007) in Trishal upazila under Mymensingh district.

Constraints of fish production: A number of constraints and risks were reported by the farmers which were inadequate technical knowledge, multiple ownership, theft, poisoning, lack of money, poor quality of fish seed etc. The single largest problem reported by $48 \%$ of respondents as lack of technical knowledge. Multiple ownership of pond was also a big problem (20\%).

From the study, it was found that multiple ownership, lack of technical knowledge, lack of quality seed, high price of feed, lack of money etc. were the main constraints of fish production in the surveyed area. Rahman (2003) stated that the major constraints of carp farming were lack of money and higher production cost. Khan et al. (1998) found that the lack of extension work for fisheries improvements caused the highest difficulty in pond fish culture. The problems encountered by the fish farmers in the surveyed area are almost similar to those recorded by Ali et al. (1991) and Biswas et al. (2001). 


\section{Livelihood Outcomes}

Livelihood outcomes can be thought of as the inverse of poverty. Contributing to the eradication of poverty and food insecurity depends on equitable access to resources, access of disadvantaged groups to sufficient, safe and nutritionally adequate food (Scones, 1998). In spite of poor resources livelihood outcomes of fish farming are positive and most of them increased their income, food security and basic needs. The survey suggests that $68 \%$ of fish farmers have improved their socio-economic condition through fish farming. Now, they have better food, cloths, housing conditions and children education. However, $32 \%$ farmers have not yet improved their status. Impact of fish farming were reflected in the process of increased saving, investment and purchasing capacity which have been increased and unemployment problem was decreased for both man and women.

\section{References}

Ahmed, N. 2001. Socio-economic aspects of freshwater prawn culture development in Mymensingh, Bangladesh. A report prepared for ICLARM.

Ali, M.A 1991. An investment on some socio-economic and technical problems in pond fish culture in two districts of Bangladesh. Bangladesh J. Aquaculture, 8(1): 47-51.

Biswas, S.S., Hossain, M.I., Mazumder, M.S. and Akteruzzaman, M. 2000. An economic analysis of pond fish culture of BRAC in some selected areas of Mymensingh district. Progress Agricult., 11(1-2): 243-249.

Carney, D. 1999. Implementing the sustainable rural livelihoods approach. In D. Carney (ed.) sustainable rural livelihoods, what contribution can we make. DFID, London, UK. 78 pp.

Chambers, R. and Conway, R. 1992. Sustainable Rural livelihoods: Practical Concept for the $21^{\text {st }}$ century, Discussion paper, IDS No. 296.

DFID. 1998. Sustainable livelihoods guidance sheets, Department for International Development (DFID), London, UK.

DFID. 2000. Strategies for achieving the international development targets: Poverty eradication and employment of women. Consulation document, Department for international development (DFID), UK.

DoF. 2005. Fisheries Fortnight Compendium, Department of Fisheries, Ministry of Fisheries and livestock, Dhaka, Bangladesh.

Hossain M.S., Dewan, S., Islam, M.S. and Hossain, S.M.A. 1992. Survey of pond fishery resources in a village of Mymensingh district. Bangladesh J. Aquaculture, 14-16: 33-37.

Khan, A.N.M.A.I., Rahman, M.M. and Islam, M.A. 1998. Factors causing difficulty in pond fish culture in a selected area of Mymensingh district. Bangladesh J. Aquaculture, 20: 23-27.

Rahman, M.M. 2003. Socio-economic aspects of carp culture development in Gazipur, Bangladesh. An M. S. thesis submitted to the Department of Fisheries Management, Bangladesh Agricultural University, and Mymensingh. $72 \mathrm{pp}$.

Sarker, R.K. 2007. Effects of training on the livelihood management of the fish farmers in Trishal upazila under Mymensingh district. M.S. thesis, Department of Fisheries Management.

Scones, I. 1998. Sustainable rural livelihoods: a frame work for analysis. IDS working paper No. 72 . Brighton: IDS, UK.

Zaman, M.M. 2006. Socio-economic condition of the fishing communities of Karotoa river. M.S. thesis, Department of Aquaculture, BAU, Mymensingh. $57 \mathrm{pp}$. 